\title{
Effect of reduced ferulate-mediated lignin/arabinoxylan cross-linking in corn silage on feed intake, digestibility, and milk production ${ }^{1}$
}

\author{
H. G. Jung, ${ }^{*} \dagger^{2}$ D. R. Mertens,$\ddagger^{3}$ and R. L. Phillips $\dagger$ \\ *USDA-ARS, Plant Science Research Unit and US Dairy Forage Research Center Cluster, St. Paul, MN 55108 \\ †Department of Agronomy and Plant Genetics, University of Minnesota, St. Paul 55108 \\ fUSDA-ARS, US Dairy Forage Research Center, Madison, WI 53706
}

\section{ABSTRACT}

Cross-linking of lignin to arabinoxylan by ferulates limits in vitro rumen digestibility of grass cell walls. The effect of ferulate cross-linking on dry matter intake (DMI), milk production, and in vivo digestibility was investigated in ad libitum and restricted-intake digestion trials with lambs, and in a dairy cow performance trial using the low-ferulate sfe corn mutant. Silages of 5 inbred corn lines were fed: W23, 2 W23sfe lines (M044 and M04-21), B73, and B73bm3. As expected, the W23sfe silages contained fewer ferulate ether cross-links and B73bm3 silage had a lower lignin concentration than the respective genetic controls. Silages were fed as the sole ingredient to 4 lambs per silage treatment. Lambs were confined to metabolism crates and fed ad libitum for a 12-d adaptation period followed by a 5 -d collection period of feed refusals and feces. Immediately following the ad libitum feeding trial, silage offered was limited to $2 \%$ of body weight. After a 2 -d adaptation to restricted feeding, feed refusals and feces were collected for $5 \mathrm{~d}$. Seventy Holstein cows were blocked by lactation, days in milk, body weight, and milk production and assigned to total mixed ration diets based on the 5 corn silages. Diets were fed for $28 \mathrm{~d}$ and data were collected on weekly DMI and milk production and composition. Fecal grab samples were collected during the last week of the lactation trial for estimation of feed digestibility using acid-insoluble ash as a marker. Silage, total mixed ration, feed refusals, and fecal samples were analyzed for crude protein, starch, neutral detergent fiber (NDF), cell wall polysaccharides, and lignin. The W23sfe silages resulted in lower DMI in the ad libitum trial than the W23 silage, but DMI did not differ in the

\footnotetext{
Received April 28, 2011.

Accepted June 27, 2011.

${ }^{1}$ Mention of a proprietary product does not constitute a recommendation or warranty of the product by USDA or the University of Minnesota and does not imply approval to the exclusion of other suitable products.

${ }^{2}$ Corresponding author: Hans.Jung@ars.usda.gov

${ }^{3}$ Current address: Mertens Innovation \& Research LLC, 6427 County Rd A, Belleville, WI 53508.
}

restricted trial. No differences were observed for NDF or cell wall polysaccharide digestibility by lambs with restricted feeding, but the amount of NDF digested daily increased for lambs fed the M04-21 W23sfe silage ad libitum. Lambs were less selective against NDF and lignin when offered W23sfe silages. The B73bm3 silage did not affect DMI or digestibility of cell walls at the restricted feeding level, but total daily NDF digested was greater at ad libitum intake. Intake, milk production, and cell wall digestibility were greater for cows fed diets containing W23sfe silages than for those fed W23 silage. Although milk production was greater for the B73bm3 diet, DMI and cell wall digestibility were not altered. Cows were less selective against cell wall material when fed both W23sfe and B73bm3 silages. Reduced ferulate cross-linking in sfe corn silage is a new genetic mechanism for improving milk production. Key words: corn silage, ferulate, digestibility, milk production

\section{INTRODUCTION}

Digestibility of forage fiber (cell walls) has long been known to be negatively associated with lignin concentration (Jung and Deetz, 1993). However, this relationship between lignin and fiber digestibility is strongest when examined across forage maturity stages and is less clear when forages are harvested at a similar maturity stage, such as corn silage or bud-stage alfalfa (Cone and Engels, 1993; Wolf et al., 1993; Jung et al., 1994). To explain the observed variation in fiber digestibility of forages with similar lignin concentrations, composition of lignin and chemical cross-linking of lignin to cell wall polysaccharides have been suggested as additional mechanisms limiting fiber digestibility (Jung and Deetz, 1993). The more digestible brown midrib (bm) mutants in corn, sorghum, and pearl millet have been shown to have both decreased lignin concentration and a shift in lignin composition (Cherney et al., 1991). Nevertheless, results from model systems and mutant Arabidopsis lines strongly suggest that alterations in lignin composition, as measured by syringyl:guaiacyl ratio, do not account for the improved fiber digestibility of bm mutants (Grabber et al., 1997; Jung et al., 1999). 
In grasses, lignin is cross-linked to arabinoxylans by ferulate molecules (Iiyama et al., 1990). These ferulates are esterified to arabinose units of arabinoxylans, and some ferulate esters subsequently form a second linkage to lignin via ether and other covalent bonds, thereby cross-linking these polymers (Ralph et al., 1992). Some ferulate esters combine to form diferulates to cross-link arabinoxylan chains, with a portion of these diferulates also becoming linked to lignin, as occurs with ferulates (Ralph et al., 1998). It has been proposed that crosslinking of lignin and arabinoxylans will impede cell wall digestibility by placing lignin in very close proximity to the polysaccharides and preventing physical access by hydrolytic microbial enzymes (Jung and Ralph, 1990; Jung and Deetz, 1993). Model studies using corn cell cultures that manipulated ferulate cross-linking and correlation analyses with grass genotypes of divergent (low vs. high ferulate ether concentration) have demonstrated that in vitro rumen cell wall degradability is negatively affected by increasing ferulate ether crosslink concentration (Grabber et al., 1998a,b; Casler and Jung, 1999; Casler et al., 2008).

A putative mutant in corn has been identified that has lower concentrations of ferulate esters in seedling leaves (Jung and Phillips, 2010). It was hypothesized that reduced deposition of ferulate esters in immature tissues would result in fewer opportunities for formation of ferulate ether cross-links in mature lignified tissues, with an associated increase in potential cell wall digestibility. Jung and Phillips (2010) showed that the seedling leaf ferulate ester (sfe) mutant had reduced concentration of ferulate ether cross-links and higher in vitro rumen cell wall digestibility for corn stover at the silage maturity stage as predicted. Small reductions in stover cell wall and lignin concentrations were also associated with the sfe mutation. Although several candidate genes have been suggested as modifiers of ferulate biosynthesis in other plant species (Nair et al., 2004; Mitchell et al., 2007; Piston et al., 2010), the gene responsible for the sfe corn mutation has not yet been identified. Plants with the sfe mutation do not exhibit the reddish-brown coloration present in $b m$ mutants; therefore, the sfe mutation is probably not caused by the same genes as those mutated in $b m$ corn mutants.

Of the 4 characterized $\mathrm{bm}$ mutations in corn, $\mathrm{bm} 3$ has been shown to cause the largest reduction in lignin concentration and improvement in digestibility (Barriere and Argillier, 1993). It has been demonstrated that corn silage from $b m 3$ mutants resulted in greater fiber digestibility and increased weight gain by ruminants with low levels of feed intake (Muller et al., 1972; Tjardes et al., 2000) and increased feed intake and milk production of high-producing dairy cows (Oba and Allen, 1999, 2000; Tine et al., 2001). Similar animal performance data are not available for the sfe mutant. The objectives of the current project were to evaluate the effect of reduced ferulate ether cross-linking of lignin to arabinoxylan in sfe corn silage on (1) feed intake and selectivity, (2) in vivo cell wall digestibility, and (3) milk production. Two studies were conducted to address these objectives, a lamb intake and digestion trial including ad libitum and restricted intake phases with $s f e$ corn silage as the sole dietary ingredient and a lactating dairy cow trial where sfe corn silage was included as part of a TMR. A bm3 corn silage was included in the trial as a positive control.

\section{MATERIALS AND METHODS}

\section{Corn Silages}

Five inbred corn lines were planted at the US Dairy Forage Research Center near Prairie du Sac, Wisconsin, in 2008. The experimental lines included the parental control line W23, 2 near-isogenic W23sfe mutant lines (M04-4 and M04-21), B73, and B73bm3. Both W23sfe lines were derived from the same original mutant plant and had shown the greatest reduction in ferulate ether cross-linking and increased in vitro rumen cell wall digestibility in an earlier plot trial involving 4 W23sfe lines (Jung and Phillips, 2010). Because inbred lines yield less biomass than commercial hybrids and seed supplies were limited, the corn lines were seeded at a low density $(\sim 59,000$ plants/ha) to maximize per-plant and total silage yield rather than yield per hectare. The 5 corn lines were grown on adjacent plots and managed according to University of Wisconsin recommendations for corn silage production. The W23 and W23sfe corn lines were chopped for silage on September 19, 2008 , and the B73 and B73bm3 lines were chopped on September 21 and 22, 2008. The silage chopper was equipped with a kernel processor. Corn silages were ensiled in 2.4-m-diameter plastic bags. One compressed, plastic-wrapped silage bale $(\sim 265 \mathrm{~kg})$ was made from each corn line using a custom-built stationary press (Digman et al., 2010).

\section{Lamb Trial}

Assignment and Covariate Period. The lamb trial was conducted from October 29 to December 10, 2008. Lambs were housed in an environmentally controlled animal room on the University of WisconsinMadison campus. The plastic-wrapped corn silage bales were fed in the lamb trial. Twenty crossbred wether lambs $(44.1 \pm 1.6 \mathrm{~kg})$ were fed a reference alfalfa hay for $6 \mathrm{~d}$ in a group pen. Body weights were taken on 3 consecutive days and lambs were assigned to 5 blocks 
based on BW. Lambs within each block were randomly assigned to silage treatment and moved to individual crates (d 1 of trial). Lambs had free access to water and a trace mineral block throughout the trial. The lambs were fed the reference alfalfa hay ad libitum during a 4-d adaptation period, followed by a 5 -d feed intake and fecal collection covariate period. Feed refusal weights were collected on d 6 through 10, and total fecal collections occurred on d 7 through 11.

Ad Libitum Phase. Beginning on d 10, lambs were fed their respective treatment corn silage ad libitum as the sole dietary ingredient. The amount of corn silage offered to each lamb was adjusted daily to achieve an approximately $10 \%$ refusal rate. After a 12 -d adaptation period to the corn silage diets, a 5-d feed intake and digestibility trial was conducted starting on d 22 . Daily grab samples of feed offered were collected and composited by silage treatment from d 22 through 26 . Individual lamb feed refusal grab samples and total feces were collected daily and composited over the 5-d collection period. Feed refusal collections began on d 23 of the trial and continued through d 27. Fecal collections began on d 24 of the trial and continued through d 28. On d 19 during the adaptation period, visual observations of lamb activity (eating, rumination, drinking, and inactivity) were recorded every $5 \mathrm{~min}$ for $24 \mathrm{~h}$.

Restricted Phase. During the restricted-intake phase of the trial, corn silage DM offered was restricted for all treatments to about $2 \%$ of $\mathrm{BW}$ to represent a maintenance level of DMI. Feed restriction began on $d$ 27. After a 2-d adjustment period to restricted intake, data collection commenced for 5 d. Feed, refusal, and fecal collections were done as in the ad libitum phase of the trial. Feed grab samples were collected from d 29 through 33, refusals were collected from d 30 through 34 , and fecal samples were collected from d 31 through 35. The short adjustment period to restricted intake was judged sufficient because although fecal weights declined during d 28 to 30 after the ad libitum feeding was ended, fecal output was consistent during $d$ 31 through 35 of fecal collection during the restricted phase.

\section{Lactation Trial}

The lactation study was conducted at the US Dairy Forage Research Center near Prairie du Sac, Wisconsin, from December 30, 2008, to March 3, 2009. Seventy Holstein cows were blocked into 14 groups based on lactation number (2.0 \pm 0.1$)$, DIM (93 $\pm 7 \mathrm{~d})$, BW (619 \pm $9 \mathrm{~kg})$, and milk production $(45.8 \pm 0.6 \mathrm{~kg} / \mathrm{d})$ during a 14-d covariate period. During the covariate period cows were fed a TMR containing approximately $17 \% \mathrm{CP}$,
$28.5 \% \mathrm{NDF}$, and $26 \%$ starch (DM basis) from $26 \%$ alfalfa silage, $31 \%$ corn silage, and $43 \%$ concentrate (DM basis). The 5 cows in each block were subsequently randomly assigned to the corn silage treatments. Ingredient and nutrient composition of the experimental diets is shown in Table 1. Diets were formulated to be similar in CP and NDF concentrations, provide $70 \%$ of dietary NDF from corn silage, and exceed CP, mineral, and vitamin requirements for $39 \mathrm{~kg} / \mathrm{d}$ of milk production (NRC, 2001). Proportions of high-moisture corn and treatment corn silages were adjusted to obtain similar NDF concentrations in the TMR across treatments. To ensure fiber utilization, diets were formulated to provide $<26 \%$ starch and $\mathrm{CP}$ that was $30 \% \mathrm{~A}$-fraction and $36 \%$ RUP as defined by NRC (2001). Cows were housed in tie stalls, fed once daily, and milked twice daily.

Cows were switched to their respective treatment diets on January 13, 2009. A rapid decline in feed intake and milk production occurred across all treatments. Because of the severity of the reduced performance, alfalfa silage in the diets was increased from 10 to $20 \%$ of diet DM (in place of concentrate ingredients) in all diets on January 20. Feed intake and milk production returned to covariate period levels over the next $7 \mathrm{~d}$. Alfalfa silage was reduced to $15 \%$ of diet DM on January 27, and the experimental period began on February 3 , when alfalfa silage was reduced to $10 \%$ of diet DM and cows returned to the experimental diets shown in Table 1. Cows were fed diets containing their respective treatment corn silage during the transition period. The cause of the decrease in performance upon the initial switch of cows to the experimental diets is unknown.

The length of the lactation trial was $28 \mathrm{~d}$ because of limited supplies of the experimental corn silages. Diets were adjusted on d 14 to account for changes in DM and NDF of the corn and alfalfa silages. Cows were fed for ad libitum intake, allowing approximately $10 \%$ daily refusals. Grab samples of the corn silages, TMR diets, and feed refusals were collected daily and composited weekly by treatment. Milk production was measured daily, and weekly means were calculated for each cow. Milk samples were collected for compositional analysis weekly at consecutive p.m. and a.m. milkings. Fecal grab samples were collected during the last week of the experiment. On 2 consecutive days, fecal grab samples were obtained from every cow during feeding after the a.m. milking, in early afternoon before the p.m. milking, and in the evening after the p.m. milking. The 6 fecal samples from each cow were composited. Lambs and cows were cared for according to separate protocols approved by the Research Animal Resource Center of the University of Wisconsin. 
Table 1. Ingredients and nutrient composition of diets fed to lactating Holstein cows

\begin{tabular}{|c|c|c|c|c|c|}
\hline \multirow[b]{2}{*}{ Composition } & \multicolumn{5}{|c|}{ Diet $^{1}$} \\
\hline & W23 & M04-4 & M04-21 & B73 & $\mathrm{B} 73 b m 3$ \\
\hline \multicolumn{6}{|l|}{ Ingredient ( $\%$ of $\mathrm{DM})$} \\
\hline Corn silage & 39.7 & 38.2 & 39.1 & 41.4 & 42.2 \\
\hline Alfalfa silage & 10.0 & 10.0 & 10.0 & 10.0 & 10.0 \\
\hline High-moisture corn & 12.0 & 13.5 & 12.6 & 10.4 & 9.5 \\
\hline Roasted soybeans & 6.0 & 6.0 & 6.0 & 6.0 & 6.0 \\
\hline Molasses & 5.0 & 5.0 & 5.0 & 5.0 & 5.0 \\
\hline Premix $^{2}$ & 27.3 & 27.3 & 27.3 & 27.3 & 27.3 \\
\hline \multicolumn{6}{|l|}{ Nutrient } \\
\hline $\mathrm{DM}(\%)$ & 53.8 & 52.6 & 51.1 & 46.1 & 46.7 \\
\hline Ash (\% of DM) & 8.5 & 8.6 & 8.6 & 8.3 & 8.3 \\
\hline $\mathrm{CP}(\%$ of $\mathrm{DM})$ & 16.5 & 15.6 & 16.8 & 16.7 & 16.3 \\
\hline Ether extract $(\%$ of $\mathrm{DM})$ & 7.0 & 6.9 & 7.4 & 7.3 & 6.7 \\
\hline Starch $(\%$ of DM $)$ & 24.5 & 26.0 & 22.3 & 22.8 & 23.1 \\
\hline $\mathrm{NDF}(\%$ of DM) & 31.0 & 30.5 & 30.9 & 31.0 & 32.1 \\
\hline Acid detergent lignin ( $\%$ of NDF) & 5.7 & 5.7 & 4.9 & 6.6 & 4.3 \\
\hline Cell wall ${ }^{3}(\%$ of DM) & 33.6 & 31.9 & 34.3 & 34.3 & 35.2 \\
\hline Klason lignin (\% of cell wall) & 14.5 & 14.6 & 14.7 & 14.0 & 13.8 \\
\hline 48-h in vitro NDF digestibility & 55.0 & 57.1 & 56.0 & 61.8 & 74.5 \\
\hline $\begin{array}{l}\text { 48-h in vitro cell wall } \\
\text { polysaccharide digestibility }\end{array}$ & 67.6 & 69.0 & 70.0 & 68.1 & 78.6 \\
\hline \multicolumn{6}{|c|}{$\begin{array}{l}{ }^{1} \text { Diets contained } 1 \text { of } 5 \text { inbred corn lines: the parental control line W23, } 2 \text { near-isogenic W23sfe mutant line } \\
(\text { M04-4 and M04-21), B73, and B73bm3. }\end{array}$} \\
\hline \multicolumn{6}{|c|}{$\begin{array}{l}{ }^{2} \text { Premix consisted (on DM basis) of } 48 \% \text { CP soybean meal }(47.87 \%) \text {, ground dry corn }(36.69 \%) \text {, Energy Booste } \\
\left(3.67 \% \text {; Milk Specialities Co., Dundee, IL), blood meal }(1.28 \%) \text {, urea }(0.66 \%), \mathrm{CaCO}_{3}(4.40 \%) \text {, CaHPC }\right. \\
(0.22 \%) \text {, Dynamate }(0.95 \% \text {; Mosaic Co., Plymouth, MN), NaHCO }(2.75 \%), \mathrm{MgO}(0.37 \%), \mathrm{NaCl}(0.73) \text {, an } \\
\text { vitamins, trace minerals, and Rumensin (0.40\%; Elanco Animal Health, Greenfield, IN). }\end{array}$} \\
\hline \multicolumn{6}{|c|}{$\begin{array}{l}{ }^{3} \text { Sum of all cell wall monosaccharide residues (glucose, xylose, arabinose, galactose, mannose, rhamnose, fucose } \\
\text { and uronic acids), Klason lignin, ferulates, and } p \text {-coumarates. }\end{array}$} \\
\hline
\end{tabular}

\section{Analytical Methods}

Composition. Feed, refusal, and fecal samples from both lamb and cow trials were dried at $60^{\circ} \mathrm{C}$ and ground to pass a 1-mm screen in a Wiley mill. Crude protein concentration was determined by the Kjeldahl method and lipids by exhaustive extraction with diethyl ether (AOAC, 1995). Samples were combusted at $450^{\circ} \mathrm{C}$ overnight to determine ash content. Starch (plus any free glucose) was measured by hydrolysis with heat-stable $\alpha$-amylase and amyloglucosidase, and resulting glucose was measured by HPLC (Dien et al., 2006). Samples were analyzed for NDF and sulfuric acid detergent lignin (ADL) in the sequential mode (Van Soest et al., 1991) using the Ankom filter bag (Ankom Technology Corp., Fairport, NY) technique. Heat-stable amylase was included in the determination of NDF.

Cell wall polysaccharide components (glucose, xylose, arabinose, galactose, mannose, rhamnose, fucose, and uronic acids) and Klason lignin were determined by a 2-stage sulfuric acid hydrolysis of starch-free, alcoholinsoluble residues prepared from feed, refusal, and fecal samples using the Uppsala Dietary Fiber method (Theander et al., 1995). Neutral sugars were derivatized and analyzed by GC. Total uronic acids in cell wall polysaccharides were determined by colorimetry on aliquots from the first-stage acid hydrolysis using glucuronic acid as the standard (Ahmed and Labavitch, 1977).

Corn silage, TMR diets, and refusal samples were analyzed for $p$-coumarates and ferulates. Starch-free, alcohol-insoluble residues were extracted with $2 M$ $\mathrm{NaOH}$ at $39^{\circ} \mathrm{C}$ to release esterified $p$-coumarates and ferulates (Jung and Shalita-Jones, 1990). Duplicate samples were extracted with $4 \mathrm{M} \mathrm{NaOH}$ at $170^{\circ} \mathrm{C}$ to release both ester and ether-linked ferulates (Iiyama et al., 1990). p-Coumaric and ferulic acids released by these alkaline extractions were quantified by HPLC. Ferulate ether cross-links were calculated as the difference between total and esterified ferulates (Iiyama et al., 1990).

Total cell wall concentration was calculated as the sum of cell wall glucose, xylose, arabinose, galactose, mannose, rhamnose, fucose, uronic acids, Klason lignin, esterified $p$-coumarates and ferulates, and etherified ferulates.

Samples of TMR diet, refusals, and feces from the lactation trial were analyzed for acid-insoluble ash (Van Keulen and Young, 1977). Digestibility was calculated using acid-insoluble ash as an internal marker (Van Soest, 1994). Data for feed and refusal composition, and amounts from wk 4 of the lactation trial were used in the digestibility calculations. 
Milk samples were analyzed for fat, protein, lactose, SCC, and MUN by AgSource Cooperative Services (Menomonie, WI).

In Vitro Digestibility. Corn silage samples collected during both phases of the lamb trial, and silage and TMR samples from the lactation trial were analyzed for in vitro rumen digestibility of NDF (IVNDFD) and cell wall polysaccharides (IVCWPD). Dried and ground silage samples were incubated with rumen fluid for 24,48 , and $96 \mathrm{~h}$, whereas TMR samples were incubated for $48 \mathrm{~h}$. Rumen fluid was collected from a fistulated, lactating Holstein cow housed on the University of Minnesota-St. Paul campus and fed a TMR including corn silage, alfalfa hay, and concentrates. Rumen fluid was collected $4 \mathrm{~h}$ postfeeding, strained through 4 layers of cheesecloth, and mixed (1:4 vol/vol) with anaerobic McDougall's buffer (McDougall, 1948) under $\mathrm{CO}_{2}$ sparging. Ankom filter bags and the Daisy rotating-jar incubator were used for measurement of IVNDFD. Incubations were conducted in 50-mL disposable, capped centrifuge tubes in a water bath for IVCWPD. To avoid problems related to starch fermentation creating a slimy layer on Ankom bag surfaces, which experience has shown to increase variability of IVNDFD measurements for high-starch samples, corn silage samples were incubated with porcine amylase overnight and the supernatant removed by centrifugation before inoculation with the rumen fluid:buffer mixture. The IVCWPD procedure did not require removal of starch. All incubations were done at $39^{\circ} \mathrm{C}$. Blank bags with glass wool were included in the IVNDFD determination, and empty tubes were used for IVCWPD to correct for NDF and cell wall polysaccharides contributed by the rumen inoculum. Residues from the in vitro rumen incubations were analyzed for NDF and cell wall polysaccharide components as described above. Care of the fistulated cow was approved by the University of Minnesota Institutional Animal Care Committee.

\section{Calculations and Statistical Analysis}

All laboratory analysis data are the mean of duplicate determinations, and data were corrected to a $100^{\circ} \mathrm{C} \mathrm{DM}$ basis. A selectivity index was calculated for both trials, where the composition of the feed consumed was calculated from appropriate feed and refusal composition and quantity data. The composition of the feed actually consumed was divided by the composition of the feed offered to obtain the selectivity index for individual nutrients. A selectivity index value $>1.0$ indicated selection for the nutrient, an index of 1.0 indicated no selection, and an index $<1.0$ indicated selection against the nutrient. Daily chewing activity (total, eating, and rumination) per gram of NDF consumed was calculated as the number of activity events recorded during the 24-h observation period and assuming each activity event lasted the full 5 min between observations.

Data for the lamb trial were analyzed as a randomized complete block design with 4 replicates and 5 corn silage treatments using PROC GLM of SAS ver. 9.1 (SAS Institute Inc., Cary, NC). Analysis of data from the covariate period indicated a significant $(P<0.05)$ difference among lambs assigned to treatment groups for DMI, but not DM digestibility of the reference alfalfa hay. Based on this result, DMI of the alfalfa hay was used as a covariate for analysis of corn silage intake and amount of NDF digested per day by lambs. Analysis of other traits did not include a covariate. Data for feed intake, milk production, and milk composition were analyzed as a randomized complete block design with weekly means as repeated measures. The PROC MIXED routine in SAS was used with a heterogeneous autoregressive covariance structure and the Satterthwaite degrees of freedom method. Cow was treated as a random effect and block and treatment were considered fixed effects. Covariate period data were not included as part of the statistical model for the lactation study because of the 3 -wk interval between the end of the covariate period and actual initiation of data collection for the trial and the intervening transition diets fed during those $3 \mathrm{wk}$. Data for nutrient digestibility and selection indices from the fecal collection period for the lactation trial were analyzed as a randomized complete block design with 14 replicates and 5 treatments using PROC GLM.

Orthogonal contrasts were used to compare treatments in both lamb and lactation trial data sets. The contrasts included W23 versus W23sfe (combination of lines M04-4 and M04-21), W23 versus M04-21, B73 versus B73bm3, and W23 versus B73. The contrast including only W23 versus W23sfe line M04-21 was included because the earlier plot trial indicated that M04-21 had a greater reduction in ferulate ether cross-linking and a greater improvement in IVNDFD and IVCWPD than observed for M04-4 (Jung and Phillips, 2010).

\section{RESULTS}

\section{Corn Silages}

The overall composition of the corn silages used for the lamb and cow trials is shown in Table 2. These mean data were based on analysis of 1 composite silage sample from the ad libitum phase and 1 composite silage sample from the restricted phase of the lamb trial, and 4 weekly composite silage samples from the lactation trial. Unfortunately, the W23 and W23sfe corn lines dried faster than anticipated and were drier than the 
Table 2. Mean composition of corn silages of inbreds W23, W23sfe lines (M04-4 and M04-21), B73, and B73bm3 fed to lambs during ad libitum and restricted intake phase digestibility studies, and included in lactating Holstein cow trial

\begin{tabular}{|c|c|c|c|c|c|}
\hline \multirow[b]{2}{*}{ Component } & \multicolumn{5}{|c|}{ Corn line } \\
\hline & W23 & M04-4 & M04-21 & B73 & $\mathrm{B} 73 \mathrm{bm} 3$ \\
\hline $\mathrm{DM}(\%)$ & 48.9 & 42.4 & 40.4 & 31.5 & 32.8 \\
\hline Ash (\% of DM) & 5.1 & 5.6 & 5.5 & 4.3 & 4.5 \\
\hline $\mathrm{CP}(\%$ of $\mathrm{DM})$ & 8.3 & 8.1 & 8.2 & 7.2 & 7.5 \\
\hline Ether extract (\% of DM) & 3.3 & 3.9 & 4.6 & 5.1 & 4.5 \\
\hline Starch (\% of DM) & 25.7 & 20.7 & 21.9 & 21.5 & 21.8 \\
\hline NDF ( $\%$ of DM) & 45.0 & 48.1 & 47.3 & 47.0 & 47.4 \\
\hline Acid detergent lignin (\% of NDF) & 4.9 & 6.7 & 4.9 & 5.3 & 4.0 \\
\hline Cell wall $^{1}(\%$ of DM) & 45.1 & 50.4 & 50.0 & 45.9 & 46.1 \\
\hline Klason lignin (\% of cell wall) & 16.1 & 16.6 & 15.9 & 15.3 & 12.9 \\
\hline Glucose (\% of cell wall) & 38.6 & 39.6 & 39.1 & 40.2 & 43.2 \\
\hline Xylose $(\%$ of cell wall $)$ & 27.5 & 26.5 & 27.7 & 29.2 & 29.0 \\
\hline Arabinose ( $\%$ of cell wall) & 6.4 & 6.1 & 6.3 & 5.2 & 5.2 \\
\hline Galactose (\% of cell wall) & 2.2 & 2.3 & 2.3 & 2.0 & 2.0 \\
\hline Mannose (\% of cell wall) & 1.4 & 1.6 & 1.6 & 1.4 & 1.5 \\
\hline Uronic acids (\% of cell wall) & 4.2 & 4.0 & 3.9 & 3.1 & 3.5 \\
\hline Ferulate esters ( $\%$ of cell wall) & 0.83 & 0.69 & 0.72 & 0.88 & 0.84 \\
\hline Ferulate ethers ( $\%$ of cell wall) & 0.92 & 0.70 & 0.67 & 0.95 & 0.90 \\
\hline$p$-Coumarate esters ( $\%$ of cell wall) & 1.76 & 1.79 & 1.72 & 1.70 & 1.01 \\
\hline
\end{tabular}

${ }^{1}$ Sum of all cell wall polysaccharide component sugars (glucose, xylose, arabinose, galactose, mannose, rhamnose, fucose, and uronic acids), Klason lignin, ferulates, and $p$-coumarates.

B73 and B73bm3 lines at harvest. Although the B73 and B73bm3 silages were similar in DM content, W23 was drier than the 2 W23sfe silages. Due to an error in communication, nondried silages samples were not retained for analysis of $\mathrm{pH}$ or fermentation acids. Our subjective assessment was that all silages were well preserved and probably had normal fermentation profiles.

As expected, the W23sfe silages had lower numerical concentrations of ferulate ether cross-links in the cell wall than W23, with M04-21 being marginally lower than M04-4 (27 and 24\% reductions, respectively). A similar difference in ferulate ether concentration was not observed between the B73 and B73bm 3 silages. The W23 silage contained more starch, and lower concentrations of NDF and total cell wall than the W23sfe silages. The B73 and B73bm3 silages were similar to the W23sfe silages in starch and NDF concentrations, but more similar to W23 for cell wall concentration. Silages for the W23sfe lines were similar in ADL and Klason lignin concentration to W23. Cell wall polysaccharide composition was similar for W23 and W23sfe silages. The B73 silage was similar to the W23 and W23sfe silages in lignin concentration; however, the B73bm 3 silage contained less ADL (24\% lower) and Klason lignin (16\% lower) than B73, as was expected. Composition of the B73 and B73bm3 silages did not differ for other major cell wall components, but $p$-coumarate ester concentration was substantially lower for the B73 $\mathrm{bm} 3$ silage relative to $\mathrm{B} 73$.
In vitro digestibility of total cell wall polysaccharides and individual polysaccharide components (with the exception of uronic acids) were uniformly greater for the W23sfe silages than for W23 after the 24-h incubation (Table 3). However, in vitro digestibility of the M04-21 silage was similar to W23 silage after the 48-h incubation and only slightly higher after $96 \mathrm{~h}$. In contrast, in vitro digestibility of M04-4 silage tended to be lower than that of W23 silage after the 48-h incubation and similar after $96 \mathrm{~h}$. In vitro digestibility of NDF did not follow the same pattern as IVCWPD. The W23 and M04-21 silages were similar in IVNDFD, and M04-4 silage was lower, at all incubation times. Greater in vitro digestibility of NDF, total cell wall polysaccharides, and all polysaccharide components was observed for the B73bm3 silage compared with the B73 silage at all 3 incubation times.

Although the silage composition data in Table 2 were averaged across both phases of the lamb trial and the lactation trial, digestibility and selection index calculations were done using composition data from the appropriate silage composites collected for each individual trial phase.

\section{Lamb Trial}

Ad libitum DMI was lower $(P<0.05)$ for lambs fed the W23 sfe silages than for W23 silage; however, this effect was due to low DMI of M04-4 silage because intake 
Table 3. Mean in vitro digestibility of NDF, total cell wall polysaccharides, and major cell wall polysaccharide component sugars of silages from corn inbred W23, W23sfe lines (M04-4 and M04-21), B73, and B73bm3 fed to lambs during ad libitum and restricted-intake phase digestibility studies and included in lactating Holstein cow trial

\begin{tabular}{|c|c|c|c|c|c|c|}
\hline \multirow[b]{2}{*}{ Component } & \multirow[b]{2}{*}{ Time (h) } & \multicolumn{5}{|c|}{ Digestibility of corn lines (\%) } \\
\hline & & W23 & M04-4 & M04-21 & B73 & $\mathrm{B} 73 b m 3$ \\
\hline \multirow[t]{3}{*}{$\mathrm{NDF}$} & 24 & 34.4 & 28.1 & 35.0 & 29.3 & 40.5 \\
\hline & 48 & 46.5 & 41.4 & 46.2 & 46.3 & 61.2 \\
\hline & 96 & 60.2 & 57.2 & 60.7 & 59.4 & 75.0 \\
\hline \multirow[t]{3}{*}{$\mathrm{CWP}^{1}$} & 24 & 36.7 & 39.7 & 51.4 & 37.4 & 61.3 \\
\hline & 48 & 63.0 & 61.6 & 62.7 & 56.4 & 72.2 \\
\hline & 96 & 68.3 & 68.1 & 70.4 & 67.3 & 81.8 \\
\hline \multirow[t]{3}{*}{ Glucose } & 24 & 36.9 & 39.7 & 51.5 & 38.1 & 63.5 \\
\hline & 48 & 66.1 & 63.7 & 65.8 & 60.8 & 77.0 \\
\hline & 96 & 71.7 & 71.1 & 73.6 & 71.2 & 85.5 \\
\hline \multirow[t]{3}{*}{ Xylose } & 24 & 31.7 & 35.1 & 48.5 & 34.2 & 56.2 \\
\hline & 48 & 57.0 & 56.2 & 58.0 & 50.5 & 67.8 \\
\hline & 96 & 63.6 & 63.5 & 65.8 & 63.1 & 79.3 \\
\hline \multirow[t]{3}{*}{ Arabinose } & 24 & 48.8 & 51.7 & 61.1 & 49.2 & 67.1 \\
\hline & 48 & 63.4 & 62.9 & 63.7 & 57.6 & 71.1 \\
\hline & 96 & 70.3 & 71.0 & 72.1 & 68.3 & 78.6 \\
\hline \multirow[t]{3}{*}{ Uronics } & 24 & 59.2 & 55.9 & 55.5 & 43.1 & 60.6 \\
\hline & 48 & 70.8 & 69.7 & 69.4 & 62.9 & 76.3 \\
\hline & 96 & 75.1 & 74.9 & 81.2 & 68.9 & 83.4 \\
\hline
\end{tabular}

${ }^{1} \mathrm{CWP}=$ total cell wall polysaccharides.

of M04-21 silage did not differ $(P>0.10)$ from that of W23 (Table 4). Although ad libitum DMI of B73 and B73bm3 silages did not differ $(P>0.10)$, lambs consumed more $(P<0.01)$ of the W23 silage than the B73 silage. Intake of DM by the lambs did not differ $(P>0.10)$ among the silages when feed offered was restricted, as was the intent of this phase of the trial.

Digestibility of total DM by lambs was lower $(P<$ $0.01)$ in the ad libitum phase and tended to be lower $(P$ $<0.10)$ in the restricted phase for W23sfe silages than for W23 (Table 4). Unlike for DMI, lamb digestibility response to the M04-21 silage was similar to that for M04-4. Crude protein digestibility was lower for lambs fed W23sfe silages in the ad libitum phase of the trial, but similar to that of lambs fed W23 silage in the restricted phase. Starch digestibility did not differ $(P>$ $0.10)$ for the W23sfe silages relative to W23 in either ad libitum or restricted intake phases. Digestibility of $\mathrm{CP}$ was lower $(P<0.05)$ for B73bm3-fed lambs compared with the B73-fed lambs during both intake phases of the trial. A trend was observed toward lower $(P<0.10)$ starch digestibility of B73bm3 compared with B73 silage in the restricted phase. During both the ad libitum and restricted phases of the lamb trial, starch digestibility was greater $(P<0.01$ and 0.05 , respectively) for the B73 silage than for the W23 silage; however, total DM

Table 4. Silage intake and digestibility of DM, CP, and starch for corn inbreds W23, W23sfe lines (M04-4 and M04-21), B73, and B73bm3 fed to lambs during ad libitum (Ad lib) and restricted intake (Res) phase digestibility studies

\begin{tabular}{|c|c|c|c|c|c|c|c|c|}
\hline Corn line & \multicolumn{2}{|c|}{ Intake ( $\mathrm{g}$ of $\mathrm{DM} / \mathrm{d})$} & \multicolumn{6}{|c|}{ Digestibility (\%) } \\
\hline W23 & 984 & 750 & 67.0 & 64.1 & 56.9 & 46.9 & 97.6 & 98.5 \\
\hline M04-4 & 839 & 751 & 59.5 & 61.5 & 40.1 & 46.1 & 97.0 & 99.3 \\
\hline M04-21 & 943 & 754 & 61.9 & 60.7 & 45.6 & 45.5 & 97.6 & 98.7 \\
\hline SEM & 22 & 27 & 1.4 & 1.2 & 2.4 & 1.9 & 0.3 & 0.2 \\
\hline \multicolumn{9}{|l|}{ Contrasts } \\
\hline W23 vs. W23sfe & $*$ & NS & $* *$ & $\dagger$ & $* * *$ & NS & NS & NS \\
\hline W23 vs. M04-21 & NS & NS & $*$ & $\dagger$ & $* *$ & NS & NS & NS \\
\hline $\mathrm{B} 73$ vs. $\mathrm{B} 73 \mathrm{bm} 3$ & NS & NS & NS & NS & $* * *$ & $*$ & NS & $\dagger$ \\
\hline W23 vs. B73 & $* *$ & NS & NS & NS & NS & NS & $* *$ & $*$ \\
\hline
\end{tabular}

$\dagger P<0.10 ;{ }^{*} P<0.05 ;{ }^{* *} P<0.01 ;{ }^{* *} P<0.001 ;$ NS: $P>0.10$ 
and $\mathrm{CP}$ digestibility did not differ $(P>0.10)$ between the 2 corn genetic backgrounds.

Digestibility of NDF by lambs did not differ $(P>$ 0.10 ) among any corn silages in the ad libitum phase (Table 5). Total cell wall polysaccharide digestibility of W23sfe silages was actually lower $(P<0.05)$ than that of W23; however, this significant effect was due to the low digestibility of the M04-4 silage. Although digestibility of cell wall glucose did not differ $(P>0.10)$ among silages fed ad libitum to lambs, digestibility of the other major polysaccharide components (xylose, arabinose, and uronic acids) was lower $(P<0.10$ to 0.01 ) for W23sfe silages than for W23. The digestibility of NDF and cell wall polysaccharides did not differ $(P>0.10)$ for the B73 and B73bm3 silages in the ad libitum phase. When the corn silages were fed at the restricted level of intake, no differences $(P>0.10)$ in digestibility of NDF or cell wall polysaccharide components were observed among any of the silage contrasts (data not shown).

Because the composition of the refusals for lambs fed the W23sfe and B73bm3 silages were different than their respective control silage refusals (data not shown), we examined the possibility that lambs fed these mutant silages were more or less selective than their counterparts fed the control silages. During the ad libitum intake phase, the percentage of offered feed that was refused by the lambs did not differ $(11.8 \pm 1.0 \%$; $P>$ $0.10)$ among the silages. Although the selectivity indices for starch, total cell wall material, ADL, and Klason lignin did not differ $(P>0.10)$ among the silages (data not shown), lambs fed the W23sfe silages were less selective for CP (1.012 and 1.035 for W23sfe and W23, respectively; $P<0.01)$ and against NDF $(0.958$ and 0.924 for W23sfe and W23, respectively; $P<0.05)$ in the silage consumed compared with lambs fed the W23 silage. Although lambs were fed to minimize refusals in the restricted phase, lambs fed the W23sfe and B73bm3 silages had lower $(P<0.05)$ refusal percentages than lambs fed their respective control silages (Table 6). Selectivity indices for the W23sfe-fed lambs indicated less selection for starch $(P<0.05)$ and less selection against total cell wall material $(P<0.01)$ and Klason lignin $(P$ $<0.01$ ), and a tendency to less selection against NDF $(P<0.10)$ than for W23-fed lambs. Only a trend was observed for less selectivity against NDF $(P<0.10)$ for B73bm3-fed lambs in the restricted phase of the trial compared with B73-fed lambs. Refusal percentage did not differ $(P>0.10)$ for lambs fed W23 and B73 silages at either intake level, and the only significant selectivity difference was a greater selectivity for CP by W23-fed lambs.

When feed intake, composition of silage consumed, and NDF digestibility were combined to calculate amount of NDF digested per day, lambs fed M04-21 digested more NDF than lambs fed W23 silage in the ad libitum phase but not in the restricted phase (Figure 1). Similarly, B73bm3-fed lambs digested more NDF daily in the ad libitum, but not restricted, phase than B73-fed lambs. Total time spent chewing (eating plus rumination) was lower for lambs fed W23sfe than for those fed W23 silage $(2.29$ and $2.76 \mathrm{~min} / \mathrm{g}$ of NDF consumed/d, respectively; $P<0.05)$ during the ad libitum phase, but not for the restricted phase. However, time spent in eating and rumination activities individually did not differ $(P>0.10)$ among silages. The B73- and B73bm3-fed lambs did not differ $(P>$ $0.10)$ in chewing activity per gram of NDF consumed.

\section{Lactation Trial}

Cows fed diets containing the W23sfe silages had greater $(P<0.01)$ DMI than cows fed the TMR containing W23 silage (Table 7 ). Total milk production

Table 5. Digestibility of NDF, total cell wall polysaccharides, and the major cell wall polysaccharide component sugars for silages of corn inbreds W23, W23sfe lines (M04-4 and M04-21), B73, and B73bm3 fed to lambs during the ad libitum intake phase digestibility study

\begin{tabular}{|c|c|c|c|c|c|c|}
\hline \multirow[b]{2}{*}{ Corn line } & \multicolumn{6}{|c|}{ Digestibility (\%) } \\
\hline & NDF & $\mathrm{CWP}^{1}$ & Glucose & Xylose & Arabinose & Uronics \\
\hline W23 & 49.4 & 57.9 & 58.6 & 54.8 & 69.8 & 64.0 \\
\hline M04-4 & 46.5 & 48.8 & 51.4 & 44.8 & 54.8 & 57.8 \\
\hline M04-21 & 52.0 & 52.2 & 55.4 & 47.0 & 59.7 & 60.1 \\
\hline B73 & 48.7 & 55.9 & 57.6 & 52.6 & 63.8 & 61.0 \\
\hline B73bm3 & 53.3 & 57.8 & 60.3 & 55.3 & 65.4 & 63.1 \\
\hline SEM & 2.5 & 2.7 & 2.6 & 3.1 & 2.8 & 1.8 \\
\hline \multicolumn{7}{|l|}{ Contrasts } \\
\hline W23 vs. W23sfe & NS & * & NS & * & $* *$ & * \\
\hline W23 vs. M04-21 & NS & NS & NS & $\dagger$ & $*$ & NS \\
\hline $\mathrm{B} 73$ vs. $\mathrm{B} 73 b m 3$ & NS & NS & NS & NS & NS & NS \\
\hline W23 vs. B73 & NS & NS & NS & NS & NS & NS \\
\hline
\end{tabular}


Table 6. Feed refusal and nutrient selectivity by lambs fed corn inbreds W23, W23sfe lines (M04-4 and M04-21), B73, and B73bm3 silages during the restricted intake phase digestibility study

\begin{tabular}{|c|c|c|c|c|c|c|c|}
\hline \multirow[b]{2}{*}{ Corn line } & \multirow[b]{2}{*}{$\begin{array}{c}\text { Refusal } \\
(\%)\end{array}$} & \multicolumn{6}{|c|}{ Selectivity index ${ }^{1}$} \\
\hline & & $\mathrm{CP}$ & Starch & NDF & $\begin{array}{l}\text { Cell } \\
\text { wall }\end{array}$ & $\begin{array}{c}\text { Acid detergent } \\
\text { lignin }\end{array}$ & $\begin{array}{c}\text { Klason } \\
\text { lignin }\end{array}$ \\
\hline W23 & 3.7 & 1.007 & 1.024 & 0.980 & 0.978 & 0.962 & 0.955 \\
\hline M04-4 & 1.3 & 1.002 & 1.008 & 0.996 & 0.996 & 0.990 & 0.995 \\
\hline M04-21 & 0.7 & 1.003 & 1.004 & 0.992 & 1.001 & 0.986 & 1.002 \\
\hline B73 & 3.9 & 1.007 & 1.018 & 0.989 & 0.986 & 0.958 & 0.971 \\
\hline \multicolumn{8}{|l|}{ Contrasts } \\
\hline W23 vs. W23sfe & * & NS & * & $\dagger$ & ** & NS & ** \\
\hline W23 vs. M04-21 & $\dagger$ & NS & $\dagger$ & NS & $* *$ & NS & $* *$ \\
\hline $\mathrm{B} 73$ vs. $\mathrm{B} 73 \mathrm{bm} 3$ & $*$ & NS & NS & NS & $\dagger$ & NS & NS \\
\hline W23 vs. B73 & NS & NS & NS & NS & NS & NS & NS \\
\hline
\end{tabular}

${ }^{1}$ Selectivity index was calculated as the composition of the feed actually consumed (offered minus refusal) divided by the composition of the feed offered. Values $>1.00$ indicate selection for a component; values $<1.00$ indicate selection against a component.

$\dagger P<0.10 ;{ }^{*} P<0.05 ;{ }^{* *} P<0.01 ; \mathrm{NS}: P>0.10$.

and $3.5 \% \mathrm{FCM}$ were also increased $(P<0.001$ and 0.05 , respectively) for cows on the W23sfe-containing diets. Milk fat percentage and fat yield were not different $(P>0.10)$ between the W23 and W23sfe diets, but a decrease $(P<0.001)$ was found in protein percentage for W23sfe-fed cows. Although milk protein yield did not differ $(P>0.10)$ for the W23 versus W23sfe contrast, the greater milk yield of the M04-21-fed cows resulted in greater protein yield $(P<0.001)$ than that in W23-fed cows. Lactose milk content did not differ $(P>0.10)$ between W23 and W23sfe diets, although

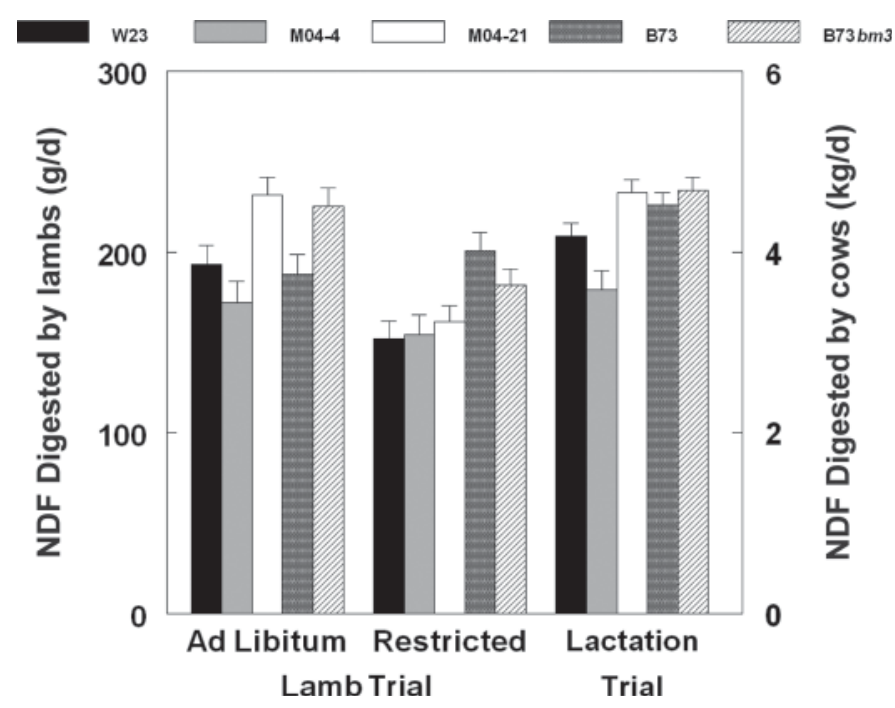

Figure 1. Amount of NDF digested per day in the ad libitum and restricted phases of the lamb trial and by cows in the lactation trial. Significant differences among treatments are discussed in text. The experimental lines included the parental control line W23, 2 nearisogenic W23sfe mutant lines (M04-4 and M04-21), B73, and B73bm3. lactose concentration was lower $(P<0.05)$ for M04-21 diets, and lactose yield was greater $(P<0.001)$ for cows fed W23sfe silages. Milk urea nitrogen concentration was lower $(P<0.001)$ for cows fed the M04-21 silage $(14.6 \mathrm{mg} / \mathrm{dL})$ compared with the W23 diet (16.0 $\mathrm{mg} / \mathrm{dL}$ ). Cows fed B73 and B73bm3 diets had similar $(P>0.10)$ DMI; however, we observed increased $(P<0.01)$ total milk production and $3.5 \%$ FCM for B73bm3-fed cows. Milk fat percentage did not differ $(P$ $>0.10)$ for the B73 and B73bm3 diets, but both protein and lactose concentrations were greater $(P<0.001)$ on B73bm3 diets. Yield of all components was increased $(P<0.05)$ for B73bm3-fed cows. Cows fed the b73bm3 diet had a lower $(P<0.001)$ MUN concentration compared with those fed the B73 diet (14.0 and $15.3 \mathrm{mg} /$ $\mathrm{dL}$, respectively). Dry matter intake and milk production were greater $(P<0.001)$ for cows fed the B73 silage compared with W23, and protein percentage was lower $(P<0.001)$ for B73-fed cows. Milk urea nitrogen concentration was higher $(P<0.05)$ for cows receiving the W23 silage diet than for those receiving B73.

Lactating cows had greater digestibility of DM $(P<$ $0.05)$, starch $(P<0.001)$, and total cell wall polysaccharides $(P<0.01)$ on the W23sfe compared with W23 silage diets (Table 8 ). Digestibility of $\mathrm{CP}$ also trended higher $(P<0.10)$ for the W23sfe diets, although NDF digestibility did not differ $(P>0.10)$. However, digestibility of all nutrients was greater $(P<0.001)$ for cows fed the M04-21 silage diet compared with the W23-fed cows. Feeding B73bm3 silage diets did not $(P>0.10)$ improve digestibility compared with B73 and a trend was observed for reduced $(P<0.10)$ CP digestibility by B73bm3-fed cows. The W23 genetic background resulted in lower digestibility of all nutrients than observed for cows fed the B73 silage. 
Table 7. Feed intake and milk production and composition of Holstein cows fed diets containing silage from corn inbreds W23, W23sfe lines (M04-4 and M04-21), B73, and B73bm3

\begin{tabular}{|c|c|c|c|c|c|c|c|c|c|}
\hline Corn line & $\begin{array}{c}\mathrm{DMI} \\
(\mathrm{kg} / \mathrm{d})\end{array}$ & $\begin{array}{c}\text { Milk } \\
(\mathrm{kg} / \mathrm{d})\end{array}$ & $\begin{array}{c}3.5 \% \mathrm{FCM} \\
(\mathrm{kg} / \mathrm{d})\end{array}$ & \multicolumn{3}{|c|}{ Milk composition (\%) } & \multicolumn{3}{|c|}{ Component yield $(\mathrm{kg} / \mathrm{d})$} \\
\hline M04-4 & 23.4 & 39.3 & 43.0 & 4.08 & 2.86 & 4.99 & 1.60 & 1.12 & 1.96 \\
\hline M04-21 & 23.3 & 41.6 & 44.1 & 3.88 & 2.92 & 4.88 & 1.61 & 1.21 & 2.03 \\
\hline B73 & 31.4 & 43.1 & 45.3 & 3.81 & 2.82 & 4.90 & 1.64 & 1.21 & 2.11 \\
\hline $\mathrm{B} 73 b m 3$ & 31.5 & 44.3 & 48.0 & 4.00 & 2.97 & 5.01 & 1.77 & 1.31 & 2.22 \\
\hline W23 vs. W23sfe & $* *$ & $* * *$ & $*$ & NS & $* * *$ & NS & NS & NS & $* * *$ \\
\hline W23 vs. M04-21 & $*$ & $* * *$ & $*$ & NS & $* * *$ & $*$ & NS & $* * *$ & $* * *$ \\
\hline $\mathrm{B} 73$ vs. $\mathrm{B} 73 \mathrm{bm} 3$ & NS & $* *$ & $* *$ & NS & $* * *$ & $* * *$ & $*$ & $* * *$ & $* * *$ \\
\hline W23 vs. B73 & $* * *$ & *** & $* * *$ & NS & $* * *$ & NS & $*$ & $* * *$ & $* * *$ \\
\hline
\end{tabular}

${ }^{*} P<0.05 ;{ }^{* *} P<0.01$; ${ }^{* * *} P<0.001 ;$ NS: $P>0.10$.

Cows fed the TMR diets containing W23sfe silage were less $(P<0.001)$ selective for starch and less selective against $\mathrm{NDF}(P<0.05)$ and Klason lignin $(P<$ $0.001)$ in feed consumed than were cows fed the W23 silage TMR (Table 9). A trend was found for W23sfefed cows to be less $(P<0.10)$ selective against total cell wall material. These selectivity patterns for cows fed mixed diets were similar to those exhibited by the lambs fed only W23 and W23sfe silages. Although lambs fed the B73bm 3 silage were not more selective than those fed B73 silage, lactating cows were more selective for starch $(P<0.001)$ and less $(P<0.001)$ selective against total cell wall material, ADL, and Klason lignin when fed B73bm3. Cows were uniformly more $(P<0.001)$ selective when fed the W23 silage containing TMR than when fed the B73 diet.

Amount of NDF digested per day by the cows did not differ $(P>0.10)$ for the W23 versus W23sfe contrast; however, cows fed the M04-21 silage-containing diet digested more NDF per day than those fed the W23 diet
(Figure 1). Cows fed the B73 and B73bm3 silages did not differ $(P>0.10)$ for amount of NDF digested daily.

\section{DISCUSSION}

Silage of the 2 near-isogenic W23sfe corn inbreds fed to lambs and cows had lower concentrations of ferulate ether cross-links than W23 silage. The reduction in ferulate ethers was of similar magnitude and in agreement with results for stover of these same lines evaluated in an agronomic plot trial (Jung and Phillips, 2010). The previous trial found higher IVNDFD and IVCWPD of the W23sfe stover, but the current in vitro rumen digestibility data for the silages only partly agree with these earlier results. Of the $2 \mathrm{~W} 23$ sfe lines included in the current report, only silage from the line with the lower concentration of ferulate ethers (M04-21) consistently had higher in vitro cell wall polysaccharide digestibility than the W23 silage. Casler and coworkers (Casler and Jung, 1999; Casler et al., 2008)

Table 8. Digestibility of dietary nutrients by lactating Holstein cows fed diets containing silage from corn inbreds W23, W23sfe lines (M04-4 and M04-21), B73, and B73bm3

\begin{tabular}{|c|c|c|c|c|c|}
\hline \multirow[b]{2}{*}{ Corn line } & \multicolumn{5}{|c|}{ Digestibility (\%) } \\
\hline & $\mathrm{DM}$ & $\mathrm{CP}$ & Starch & NDF & $\mathrm{CWP}^{1}$ \\
\hline W23 & 71.1 & 68.7 & 93.3 & 57.7 & 61.9 \\
\hline M04-4 & 69.1 & 65.1 & 93.7 & 56.3 & 64.3 \\
\hline M04-21 & 78.1 & 76.9 & 96.9 & 65.2 & 69.5 \\
\hline B73 & 79.4 & 78.7 & 97.4 & 62.0 & 73.4 \\
\hline B73bm3 & 78.2 & 75.9 & 98.1 & 62.5 & 72.4 \\
\hline SEM & 0.9 & 1.1 & 0.5 & 1.7 & 1.4 \\
\hline \multicolumn{6}{|l|}{ Contrasts } \\
\hline W23 vs. W23sfe & $*$ & $t$ & $* *$ & NS & $* *$ \\
\hline W23 vs. M04-21 & $* * *$ & $* * *$ & $* * *$ & $* *$ & $* * *$ \\
\hline $\mathrm{B} 73$ vs. $\mathrm{B} 73 \mathrm{bm} 3$ & NS & $\dagger$ & NS & NS & NS \\
\hline W23 vs. B73 & $* * *$ & $* * *$ & $* * *$ & $\dagger$ & $* * *$ \\
\hline
\end{tabular}


Table 9. Nutrient selectivity by lactating Holstein cows fed diets containing silage from corn inbreds W23, W23sfe lines (M04-4 and M04-21), B73, and B73bm3 during the week when the digestibility trial was conducted

\begin{tabular}{|c|c|c|c|c|c|c|}
\hline \multirow[b]{2}{*}{ Corn line } & \multicolumn{6}{|c|}{ Selectivity index ${ }^{1}$} \\
\hline & $\mathrm{CP}$ & Starch & NDF & $\begin{array}{l}\text { Cell } \\
\text { wall }\end{array}$ & $\begin{array}{c}\text { Acid } \\
\text { detergent } \\
\text { lignin }\end{array}$ & $\begin{array}{c}\text { Klason } \\
\text { lignin }\end{array}$ \\
\hline W23 & 1.014 & 1.030 & 0.977 & 0.979 & 0.943 & 0.918 \\
\hline M04-4 & 1.014 & 1.026 & 0.984 & 0.985 & 0.942 & 0.953 \\
\hline M04-21 & 1.014 & 1.015 & 0.976 & 0.968 & 0.942 & 0.928 \\
\hline B73 & 1.005 & 0.995 & 0.983 & 0.986 & 0.981 & 0.979 \\
\hline $\mathrm{B} 73 \mathrm{bm} 3$ & 1.006 & 1.004 & 0.985 & 1.000 & 0.971 & 0.995 \\
\hline SEM & 0.001 & 0.001 & 0.001 & 0.001 & 0.003 & 0.003 \\
\hline \multicolumn{7}{|l|}{ Contrasts } \\
\hline W23 vs. W23sfe & NS & $* * *$ & $*$ & $\dagger$ & NS & $* * *$ \\
\hline W23 vs. M04-21 & NS & $* * *$ & NS & $* * *$ & NS & $*$ \\
\hline $\mathrm{B} 73$ vs. B73bm3 & NS & $* * *$ & NS & $* * *$ & $*$ & $* * *$ \\
\hline W23 vs. B73 & $* * *$ & $* * *$ & $* * *$ & $* * *$ & $* * *$ & $* * *$ \\
\hline
\end{tabular}

${ }^{1}$ Selectivity index was calculated as the composition of the feed actually consumed (offered minus refusal) divided by the composition of the feed offered. Values $>1.00$ indicate selection for a component; values $<1.00$ indicate selection against a component.

$\dagger P<0.10 ;{ }^{*} P<0.05 ;{ }^{* *} P<0.001 ; \mathrm{NS}: P>0.10$.

found negative correlations between the concentration of ferulate ether cross-links and IVNDFD for several perennial grasses; therefore, it would be expected that the corn inbred line (M04-21) with the lower ferulate ether cross-link concentration would exhibit the greater increase in digestibility. Given the relatively small increase in digestibility observed by Jung and Phillips (2010) for W23sfe lines in a highly replicated plot trial, it is not unexpected that similar small increases in digestibility were not evident for the nonreplicated silages. Jung and Phillips (2010) concluded that all of the improvement in W23sfe stover in vitro digestibility occurred during the first $24 \mathrm{~h}$ of incubation with rumen fluid, indicating that the effect of the sfe mutation was on the more rapidly digestible cell wall fraction. In vitro digestibility data for whole-plant corn silage generally supported this conclusion. The improvement for in vitro digestibility associated with the bm3 mutation (Barriere and Argillier, 1993; Oba and Allen, 1999, 2000) was evident in the B73bm3 silage.

One concern in interpreting the animal response data is that the silages differed in DM content. The higher DM of the W23 silage probably reflected a greater grain content of this line than for the W23sfe silages. Jung and Phillips (2010) reported that W23sfe lines produced more total biomass than W23 but that all of the extra biomass was in the stover fraction. Because corn grain typically dries faster than stover (Lauer, 2010), a lower grain:stover ratio in the W23sfe silages should slow preharvest whole-plant moisture loss. The greater starch and lower NDF and cell wall concentrations of the W23 silage than the W23sfe silages would be expected with a higher grain:stover ratio for the
W23 silage. Although silage DM and genetic line (W23 vs. W23sfe) were confounded, we have no reason to believe that the wetter W23sfe silages directly affected animal response.

As expected, the B73bm3 silage had less lignin than did B73. Although Jung and Phillips (2010) found slightly reduced lignification of W23sfe stover compared with its control, a similar small reduction in lignin was not apparent for the silages in the current study. The lower $p$-coumarate ester concentration of B73 $\mathrm{bm} 3$ silage reflects the shift observed in lignin composition for the bm3 mutation toward a lower syringyl:guaiacyl ratio because $p$-coumarates are specifically esterified to syringyl monolignol units (Ralph et al., 1994). No similar change in $p$-coumarate esters was observed or expected for the sfe mutant. Stems from bm3 corn stover have a lower concentration of ferulate ether cross-links compared with isogenic controls (Goto et al., 1994; Lam et al., 1996), but very little difference was observed between the B73bm 3 and B73 silages in the current study.

Because this is the first report on the in vivo effect of reduced ferulate cross-linking in corn silage on animal performance, no literature is available for comparison. Direct comparisons between the W23sfe and B73bm3 silages are difficult because the 2 mutations have different genetic backgrounds (W23 and B73, respectively). Extensive literature has documented that corn genetic lines differ markedly in composition and digestibility even in the absence of major mutations such as bm3 (Wolf et al., 1993; Argillier and Barriere, 1996). Composition and in vitro digestibility data for the silages and animal response data from the 2 genetic backgrounds differed for numerous traits; therefore, 
any differences between the sfe and bm3 mutations cannot be separated from genetic background effects. By necessity, our discussion of the results for the animal trials will limit comparisons between the sfe and bm3 mutations to subjective comments rather than statistical differences.

Cows fed the W23sfe silages as part of a TMR exhibited greater DMI and milk production. Contrary to previous results (Oba and Allen, 1999; Tine et al., 2001), we did not observe an increase in DMI for cows fed the B73bm3 mutant silage compared with B73. However, 3.5\% FCM production was improved $6.0 \%$ for the B73bm 3 silage diet relative to the B73 control and this increase was similar $(6.8 \%)$ to that reported earlier (Oba and Allen, 1999). The increases in 3.5\% FCM production for the sfe mutant were 2.9 and $5.5 \%$ for the M04-4 and M04-21 silages, respectively. The improvement in FCM for the M04-21 silage diet was similar in magnitude to the increase observed for the B73bm3 silage in the trial. Although cows fed the B73bm3 diet produced $8.8 \%$ more FCM than cows fed the M04-21 silage, this difference can be attributed to differences between the 2 corn genetic backgrounds, not the 2 mutations per se, because the B73 diet supported $8.4 \%$ greater milk production compared with the W23 silage. Neither mutation altered milk fat concentration; however, the W23sfe silages reduced protein percentage, whereas B73bm3 increased protein percentage. The W23sfe silages did not have a consistent effect on lactose concentration, whereas B73bm3 increased lactose percentage. These milk composition shifts for the B73bm 3 silage match the pattern reported by Oba and Allen (1999) for bm3 corn silage.

In vitro digestibility of cell wall material has consistently been shown to increase when the bm 3 mutation is incorporated into different corn genetic backgrounds (Mechin et al., 1998). Although increased in vivo cell wall digestibility is often observed for bm3 corn silage (Muller et al., 1972; Tjardes et al., 2000; Tine et al., 2001), such a positive digestibility response is not always the case (Rook et al., 1977; Oba and Allen, 2000). In the current trial we did not detect changes in the digestion coefficients for cell wall material or amount of NDF digested daily by cows fed the B73bm3 diet; however, digestibility of cell wall polysaccharides was greater for the W23sfe diets. Again, the greatest improvement in cell wall digestibility was seen for the M04-21 silage, which also resulted in a greater amount of NDF digested per day. The lack of a response for the B73bm3 silage was puzzling, particularly because DMI was also not different for this silage and its control. Oba and Allen (1999) theorized that cows fed the bm3 silage-containing diet in their study did not exhibit greater in vivo NDF digestibility because DMI was increased on the $b m 3$ diet and a negative relationship existed between DMI and NDF digestibility.

Lambs fed the W23sfe silages did not exhibit greater cell wall digestibility relative to their respective control silages, although the amount of NDF digested per day was greater for the M04-21 silage in the ad libitum phase only. This result was surprising given the improvements in IVNDFD and IVCWPD found for the W23sfe silages and the previous report on W23sfe stover (Jung and Phillips, 2010). Of particular concern was the lack of an increase in digestibility for the B73bm3 silage when the bm 3 mutation has consistently been shown to improve NDF digestibility by lambs and cattle at low levels of feed intake (Muller et al., 1972; Weller and Phipps, 1986; Tjardes et al., 2000; Tine et al., 2001). Clearly, some factor(s) in this digestion trial was preventing the lambs from achieving the higher NDF digestibility reasonably expected for the B73bm3 silage and, possibly, the W23sfe silages. One possible explanation for the lack of a positive response by lambs to the sfe mutant may relate to selectivity of the silage consumed.

Although selectivity differed little between lambs fed B73 and B73bm 3 silages, the W23sfe-fed lambs clearly consumed a diet richer in cell wall material compared with the lambs fed the W23 silage. Consumption of forages with higher concentrations of cell wall material generally results in lower total DM digestibility because non-cell-wall nutrients are more digestible than cell walls (Van Soest, 1994), and cell wall digestibility declines because the degree of cell wall lignification is usually greater as forages accumulate higher concentrations of cell wall (Jung and Deetz, 1993). Therefore, the lower DM and cell wall digestibility observed for lambs fed W23sfe silages ad libitum compared with W23 was perhaps expected given the small degree of improvement in IVNDFD and IVCWPD for the sfe mutant (Jung and Phillips, 2010) and the consumption of W23sfe silage with more cell wall material than was consumed by lambs fed W23 silage. Reduced in vivo DM and cell wall digestibility was not observed for W23sfe in the restricted intake phase of the lamb trial. An increase in digestibility would be expected at restricted intake due to the longer rumen retention time (Oba and Allen, 1999); however, lambs were even less selective against cell wall material in W23sfe silage consumed in the restricted phase of the trial. It remains unclear why cell wall digestibility was not increased for the B73bm3 silage in the lamb trial because we observed little difference in selectivity of lambs fed the B73 and B73bm3 silages. Similar to lambs fed the W23sfe silages, lactating cows fed W23sfe diets were also less selective against cell wall material than those fed the W23 diet. Unlike lambs fed the B73bm3 silage, which showed no change in selectivity, cows fed a B73bm3 TMR were 
less selective against cell wall material than cows on the B73 silage. The cause for the reduced selectivity of cows fed the 2 corn silage mutants is unknown.

It has been suggested that diferulate cross-linking of Chinese water chestnut cell wall polymers contributes to the maintenance of crispness even when cooked (Parker et al., 2003). The W23sfe lines have recently been found to contain lower concentrations of both ester-only and ester/ether linked diferulates (R. D. Hatfield, USDA-ARS, Madison, WI, and H. G. Jung, unpublished data). Perhaps the lower concentration of diferulate cross-links and ferulate ether cross-links cause the sfe mutant to be more fragile, resulting in greater particle size breakdown during silage chopping or mastication. Rupture of lignified tissues is essential for exposure of potentially digestible interior cell wall surfaces to microbial attack (Jung et al., 2000; Jung and Engels, 2001). Unfortunately, data were not collected in the current trials on silage particle size after chopping or particle size breakdown during and after ingestion. However, the observation that lambs fed the W23sfe silages spent less total time chewing per gram of NDF consumed may indicate greater fragility due to the sfe mutation.

\section{CONCLUSIONS}

Silage of the sfe corn mutant had reduced ferulate ether cross-linking and higher in vitro cell wall digestibility, and resulted in increased DMI and milk production by lactating cows. In vivo digestibility of cell walls by cows was greater on sfe corn silage-containing diets, but not by lambs fed sfe silages at a restricted level of feed intake. Both cows and lambs were less selective against cell wall material when fed sfe silages, which may have contributed to the lack of an in vivo digestibility response by the lambs. Surprisingly, the low-lignin bm3 corn silage was not more digestible by lambs or cows, and did not increase DMI by cows. Milk production was greater on $b m 3$ diets, but the source of the extra nutrients to support the additional milk is unknown. The relative magnitude of the improved milk production for the sfe and bm3 mutants was similar. Combining sfe and bm 3 mutations in the same corn line may provide even greater improvements in animal performance because these mutations involve different genes and appear to have different modes of action (ferulate cross-linking and lignin concentration).

\section{ACKNOWLEDGMENTS}

The authors thank Wilfred Vermerris (University of Florida, Gainesville) for providing the seed of the B73 and B73bm3 inbred corn lines, Richard Jeo (USDAARS, Madison, WI) and many undergraduates for thousands of hand pollinations to increase seed supplies of the 5 inbred lines and laboratory analysis of samples at St. Paul, Minnesota, and staff at the US Dairy Forage Research Center (Madison, WI) for producing the corn silages and for animal care. This research was funded by the USDA-Agricultural Research Service.

\section{REFERENCES}

Ahmed, A. E. R., and J. M. Labavitch. 1977. A simplified method for accurate determination of cell wall uronide content. J. Food Biochem. 1:361-365.

AOAC. 1995. Official Methods of Analysis. 16th ed. Association of Official Analytical Chemists, Arlington, VA.

Argillier, O., and Y. Barriere. 1996. Genotypic variation for digestibility and composition traits of forage maize and their changes during the growing season. Maydica 41:279-285.

Barriere, Y., and O. Argillier. 1993. Brown-midrib genes of maize: A review. Agronomie 13:865-876.

Casler, M. D., and H. G. Jung. 1999. Selection and evaluation of smooth bromegrass clones with divergent lignin and etherified ferulic acid concentration. Crop Sci. 39:1866-1873.

Casler, M. D., H. G. Jung, and W. K. Coblentz. 2008. Clonal selection for lignin and etherified ferulates in three perennial grasses. Crop Sci. 48:424-433.

Cherney, J. H., D. J. R. Cherney, D. E. Akin, and J. D. Axtell. 1991. Potential of brown-midrib, low-lignin mutants for improving forage quality. Adv. Agron. 46:157-198.

Cone, J. W., and F. M. Engels. 1993. The influence of ageing on cell wall composition and degradability of three maize genotypes. Anim. Feed Sci. Technol. 40:331-342.

Dien, B. S., H. G. Jung, K. P. Vogel, M. D. Casler, J. F. S. Lamb, L. Iten, R. B. Mitchell, and G. Sarath. 2006. Chemical composition and response to dilute-acid pretreatment and enzymatic saccharification of alfalfa, reed canarygrass, and switchgrass. Biomass Bioenergy 30:880-891.

Digman, M. F., K. J. Shinners, R. E. Muck, and B. S. Dien. 2010. Pilot-scale on-farm pretreatment of perennial grasses with dilute acid and alkali for fuel ethanol production. Trans. ASAE $53: 1007-1014$

Goto, M., J. Matsuoka, T. Sato, H. Ehara, and O. Morita. 1994. Brown midrib mutant maize with reduced levels of phenolic acids ether-linked to the cell walls. Anim. Feed Sci. Technol. 48:27-38.

Grabber, J. H., R. D. Hatfield, and J. Ralph. 1998b. Diferulate crosslinks impede the enzymatic degradation of non-lignified maize walls. J. Sci. Food Agric. 77:193-200.

Grabber, J. H., J. Ralph, and R. D. Hatfield. 1998a. Ferulate crosslinks limit the enzymatic degradation of synthetically lignified primary walls of maize. J. Agric. Food Chem. 46:2609-2614.

Grabber, J. H., J. Ralph, R. D. Hatfield, and S. Quideau. 1997. p-Hydroxyphenyl, guaiacyl, and syringyl lignins have similar inhibitory effects on wall degradability. J. Agric. Food Chem. 45:2530-2532.

Iiyama, K., T. B. T. Lam, and B. A. Stone. 1990. Phenolic acid bridges between polysaccharides and lignin in wheat internodes. Phytochemistry 29:733-737.

Jung, H. G., and D. A. Deetz. 1993. Cell wall lignification and degradability. Pages 315-346 in Forage Cell Wall Structure and Digestibility. H. G. Jung, D. R. Buxton, R. D. Hatfield, and J. Ralph, ed. ASA-CSSA-SSSA, Madison, WI.

Jung, H. G., and F. M. Engels. 2001. Alfalfa stem tissues: Rate and extent of cell-wall thinning during ruminal degradation. Neth. J. Agric. Sci. 49:3-13.

Jung, H. G., M. A. Jorgensen, J. G. Linn, and F. M. Engels. 2000 Impact of accessibility and chemical composition on cell-wall polysaccharide degradability of maize and lucerne stems. J. Sci. Food Agric. 80:419-427.

Jung, H. G., W. Ni, C. C. S. Chapple, and K. Meyer. 1999. Impact of lignin composition on cell-wall degradability in an Arabidopsis mutant. J. Sci. Food Agric. 79:922-928. 
Jung, H. G., and R. L. Phillips. 2010. Putative seedling ferulate ester (sfe) maize mutant: Morphology, biomass yield, and stover cell wall composition and rumen degradability. Crop Sci. 50:403-418.

Jung, H. G., and J. Ralph. 1990. Phenolic-carbohydrate complexes in plant cell walls and their effect on lignocellulose utilization. Pages 173-182 in Microbial and Plant Opportunities to Improve Lignocellulose Utilization by Ruminants. D. E. Akin, L. G. Ljungdahl, J. R. Wilson, and P. J. Harris, ed. Elsevier, New York, NY.

Jung, H. G., and S. C. Shalita-Jones. 1990. Variation in the extractability of esterified $p$-coumaric and ferulic acids from forage cell walls. J. Agric. Food Chem. 38:397-402.

Jung, H. G., R. R. Smith, and C. S. Endres. 1994. Cell-wall composition and degradability of stem tissue from lucerne divergently selected for lignin and in vitro dry matter disappearance. Grass Forage Sci. 49:1-10.

Lam, T. B. T., K. Iiyama, and B. A. Stone. 1996. Lignin and hydroxycinnamic acids in walls of brown midrib mutants of sorghum, pearl millet and maize stems. J. Sci. Food Agric. 71:174-178.

Lauer, J. G. 2010. Synchrony of silage grain and stover drydown. Field Crops 28.5-80. Accessed July 19, 2011. http://corn.agronomy. wisc.edu/AA/A080.aspx.

McDougall, E. I. 1948. Studies on ruminant saliva: I. The composition and output of sheep's saliva. Biochem. J. 43:99-109.

Mechin, V., O. Argillier, Y. Barriere, and V. Menanteau. 1998. Genetic variation in stems of normal and brown-midrib 3 maize ibred lines. Towards similarity for in vitro digestibility and cell wall composition. Maydica 43:205-210.

Mitchell, R. A. C., P. Dupree, and P. R. Shewry. 2007. A novel bioinformatics approach identifies candidate genes for the synthesis and feruloylation of arabinoxylan. Plant Physiol. 144:43-53.

Muller, L. D., V. L. Lechtenberg, L. F. Bauman, R. F. Barnes, and C. L. Rhyherd. 1972. In vivo evaluation of a brown midrib mutant of Zea mays L. J. Anim. Sci. 35:883-889.

Nair, R. B., K. L. Bastress, M. O. Riuegger, J. W. Denault, and C. Chapple. 2004. The Arabidopsis thaliana reduced epidermal fluorescence 1 gene encodes an aldehyde dehydrogenase involved in ferulic acid and sinapic acid biosynthesis. Plant Cell 16:544-554.

NRC. 2001. Nutrient Requirements of Dairy Cattle. 7th rev. ed. National Academy Press, Washington, DC.

Oba, M., and M. S. Allen. 1999. Effects of brown midrib 3 mutation in corn silage on dry matter intake and productivity of high yielding dairy cows. J. Dairy Sci. 82:135-142.

Oba, M., and M. S. Allen. 2000. Effects of brown midrib 3 mutation in corn silage on productivity of dairy cows fed two concentrations of dietary neutral detergent fiber: 3 . Digestibility and microbial efficiency. J. Dairy Sci. 83:1350-1358.

Parker, C. C., M. L. Parker, A. C. Smith, and K. W. Waldron. 2003. Thermal stability of texture in Chinese water chestnut may be de- pendent on 8,8'-diferulic acid (aryltetralyn form). J. Agric. Food Chem. 51:2034-2039.

Piston, F., C. Uauy, L. Fu, J. Langston, J. Labavitch, and J. Dubcovsky. 2010. Down-regulation of four putative arabinoxylan feruloyl transferase genes from family PF02458 reduced ester-linked ferulate content of in rice cell walls. Planta 231:677-691.

Ralph, J., R. D. Hatfield, J. H. Grabber, H. G. Jung, S. Quideau, and R. F. Helm. 1998. Cell wall cross-linking in grasses by ferulates and diferulates. Pages 209-236 in Lignin and Lignan Biosynthesis. N. G. Lewis and S. Sarkanen, ed. ACS, Washington, DC.

Ralph, J., R. D. Hatfield, S. Quideau, R. F. Helm, J. H. Grabber, and H. G. Jung. 1994. Pathway of $p$-coumaric acid incorporation into maize lignin as revealed by NMR. J. Am. Chem. Soc. 116:94489456 .

Ralph, J., R. F. Helm, S. Quideau, and R. D. Hatfield. 1992. Lignin-feruloyl ester cross-links in grasses. Part 1. Incorporation of feruloyl esters into coniferyl alcohol dehydrogenation polymers. J. Chem. Soc., Perkin Trans. 1 2961-2969.

Rook, J. A., L. D. Muller, and D. B. Shank. 1977. Intake and digestibility of brown-midrib corn silage by lactating dairy cows. J. Dairy Sci. 60:1894-1904.

Theander, O., P. Aman, E. Westerlund, R. Andersson, and D. Pettersson. 1995. Total dietary fiber determined as neutral sugar residues, uronic acid residues, and Klason lignin (The Uppsala Method): Collaborative study. J. AOAC Int. 78:1030-1044.

Tine, M.A., K.R. Mcleod, R.A. Erdman, and R.L. Baldwin VI.. 2001. Effects of brown midrib corn silage on the energy balance of dairy cattle. J. Dairy Sci. 84:885-895.

Tjardes, K. E., D. D. Buskirk, M. S. Allen, N. K. Ames, L. D Bourquin, and S. R. Rust. 2000. Brown midrib-3 corn silage improves digestion but not performance of growing beef steers. J. Anim. Sci. 78:2957-2965.

Van Keulen, J., and B. A. Young. 1977. Evaluation of acid-insoluble ash as a natural marker in ruminant digestion studies. J. Anim. Sci. 44:282-287.

Van Soest, P. J. 1994. Nutritional Ecology of the Ruminant. 2nd ed. Cornell University, Ithaca, NY.

Van Soest, P. J., J. B. Robertson, and B. A. Lewis. 1991. Methods for dietary fiber, neutral detergent fiber, and non-starch polysaccharides in relation to animal nutrition. J. Dairy Sci. 74:3583-3597.

Weller, R. F., and R. H. Phipps. 1986. The feeding value of normal and brown midrib-3 maize silage. J. Agric. Sci. Camb. 106:31-35.

Wolf, D. P., J. G. Coors, K. A. Albrecht, D. J. Undersander, and P. R. Carter. 1993. Forage quality of maize genotypes selected for extreme fiber concentrations. Crop Sci. 33:1353-1359. 